\title{
イオンビームによって改質したコラーゲンの 内皮化促進ステントへの応用と動物実験による考察
}

\author{
鈴木 嘉昭 ${ }^{1}$, 氏家 弘 ${ }^{2}$, 堀 智勝 ${ }^{2}$, 杉田 洋一 ${ }^{3}$
}

\section{In Vivo Animal Study of $\mathrm{He}^{+}$Ion Irradiated Collagen for the Development of Small Diameter Stent}

\author{
Yoshiaki SuzukI, Ph.D., ${ }^{1}$ Hiroshi UJIIE, M.D., ${ }^{2}$ Tomokatsu HoRI, M.D., ${ }^{2}$ and \\ Youichi SuGITA, M.D. ${ }^{3}$ \\ ${ }^{1}$ Advanced Development and Supporting Center, RIKEN, ${ }^{2}$ Department of Neurosurgery, \\ Neurological Institute, Tokyo Women's Medical University, Tokyo, Japan, and ${ }^{3}$ Center for \\ Artificial Organ Development, Baylor College of Medicine, Texas, U.S.A.
}

\begin{abstract}
Summary: In recent years, the stent technology available for endovascular treatment of aortic dissections has advanced tremendously. It is now possible to apply this minimally invasive technique to a wider range of pathology. The aim of this study was to develop anti-thrombogenic coronary stent using ion-beam technology. Our previous study indicted that $\mathrm{He}^{+}$-irradiated collagen surface with a fluence of $1 \times 10^{14}$ ions $/ \mathrm{cm}^{2}$ has excellent antithrombogenicity and cell attachment property. The ion beam irradiated collagen-coated Ni-Ti and available SUS stents demonstrated a high antithrombogenicity and endothelialization in animal studies. The implantation of ions into a collagencoated surface is a promising approach for developing a new stent. It is therefore very likely that ion-implanted collagen-coated stents will be clinically applicable.
\end{abstract}

血小板剤の導入によって行われている.また遠隔期の問題 としては初期には再狭窄の問題が生じてはいたが，現在は シロリムスなどの免疫抑制剂, 細胞増殖抑制剂の固定化に よって再狭窄の問題はほぼ解決された。しかしこの薬物徐 放性ステント(drug eluting stent: DES)の使用でも患者は 遅発性血栓性閉塞や日常的に塩酸チクロピジンなど強力な 抗血小板剂の投与を余儀なくされ，これらの問題を解決で きる次世代のステントが期待されているのが現状である.

\footnotetext{
${ }^{1}$ 理化学研究所 先端技術開発支援センター, ${ }^{2}$ 東京女子医科大学 脳神経外科, ${ }^{3}$ ベイラー医科大学 (受稿日 2008.1.7) (脱稿日 2008. 5. 8) 〔連絡先：干351-0198 埼玉県和光市広沢 2-1 理化学研究所 先端技術開発支援センター ビームアプリケーションセンター 鈴 木嘉昭] [Address correspondence: Yoshiaki SuzukI, M.D., Advanced Development and Supporting Center, RIKEN, 2-1 Hirosawa, Wako, Saitama 351-0198, Japan]
} 


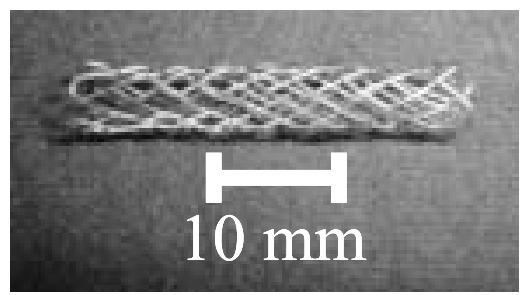

Material : Ti-Ni Alloy

Material diameter : $0.15 \mathrm{~mm}$

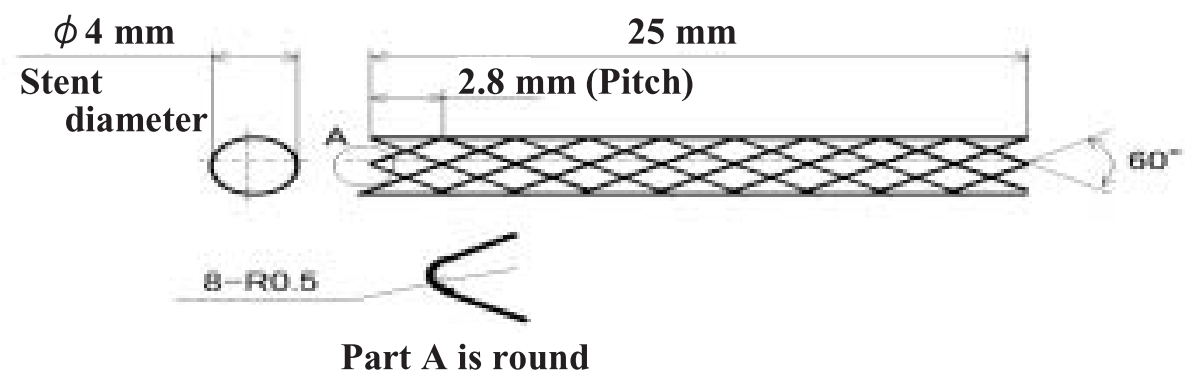

Fig. 1 A schematic diagram of Ti-Ni stent.

また脳神経外科領域では 1998 年に Guglielmi detachable coil $(\mathrm{GDC})^{1) 2}$ が本邦に導入され, そして 2008 年より頸動 脈狭窄性病変に対するステント使用の認可がおりた。しか し欧米を中心に脳血管病変を血管内外科で治療するという 趨勢はさらに加速し, 日本ではまだ臨床使用どころか紹介 すらされていない脳血管用 stentまたは covered stentに よる治療も諸外国では始まっている ${ }^{7)}$. しかし頭蓋内脳血 管は 3-4 mm と細く, 血管壁が薄く直線状の部分が少ない ため血栓化が生じやすいためステントの開発は, 非常に難 しい.

強力な抗血小板剤の投与の解決には血液凝固を抑制する 表面 (抗血栓性表面)の導入が考えられ，また遠隔期の過度 の細胞増殖による再狭窄は, 早期に内皮化を誘導し, 線維 芽細胞などの過度の細胞増殖を抑制する表面をステントに 導入することでこれらの問題が軽減されると思われる.

われわれは細胞外マトリックスと呼ばれるタンパク質に イオンビームを照射すると, 照射条件によって血小板粘着 性, 細胞接着性の制御が可能であることを報告している5 6). 特にコラーゲンへの $\mathrm{He}^{+}$イオンビーム照射によって血 小板粘着が抑制され，かつ内皮細胞の接着を同時に生じる ことを明らかにして，小口径人工血管，損傷血管修復材に 応用し, 高い開存率, 自己修復性を得た ${ }^{4)}$ ) . 本実験は, 血小板粘着抑制と同時に内皮化を誘導するこの表面をステ ント表面に導入して動物実験によって抗血栓性，内皮化の 誘導について検討した。

イオンビーム照射技術とは，添加を目的とする粒子を高 真空 $\left(10^{-4} \mathrm{~Pa}.\right)$ 中でイオン化し, 数十 $\mathrm{kV}$ から数 MVに加 速して固体基板に添加する方法である，イオン源で作られ
加速されたイオンビームは, 質量分離されるため, イオン の純度がきわめてよい. また加速エネルギー, 照射量など 制御性が高く, 再現性, 均一性のよい加工が可能である. また照射材料の構造変化に対するイオンビーム照射効果が 解析しやすい利点を有する. この方法は添加効果を目的に した例ではすでにシリコンへの不純物添加法として確立さ れた技術である.また表面改質法の中で最も高いエネルギ 一のイオンを用いることを特徴とする.

目的

ニチノール製ステントおよび市販の冠動脈用ステント内 面にタイプIコラーゲンをコーティングして $\mathrm{He}^{+}$イオンビ 一ム照射することで，抗血栓性と同時に内皮化を誘導する 表面を作成し, 動物実験によってこれらのステントの有用 性を実証することを目的とした。

\section{実験方法}

\section{1. ステント}

Ti-Ni 合金線 (直径 $0.15 \mathrm{~mm}$ ) をステント内径 $4 \mathrm{~mm}$, 長さ $25 \mathrm{~mm}$ にダイヤモンドブレード編組し, Fig. 1 に示すニチ ノール製ステントを作成した。また市販されているジョン ソンエンドジョンソン社ベアステント (BXステント), 薬 物徐放性 Cypher ステントを加えて用いた。

\section{2. コラーゲンコートおよびイオンビーム照射}

Fig. 2 に示すようにステントをディップコート法により タイプIコラーゲン (CELLGEN, Bovine dermis collagen, KOKEN Co. Japan) をコートした. 乾燥後, $\mathrm{He}^{+}$を加速電 


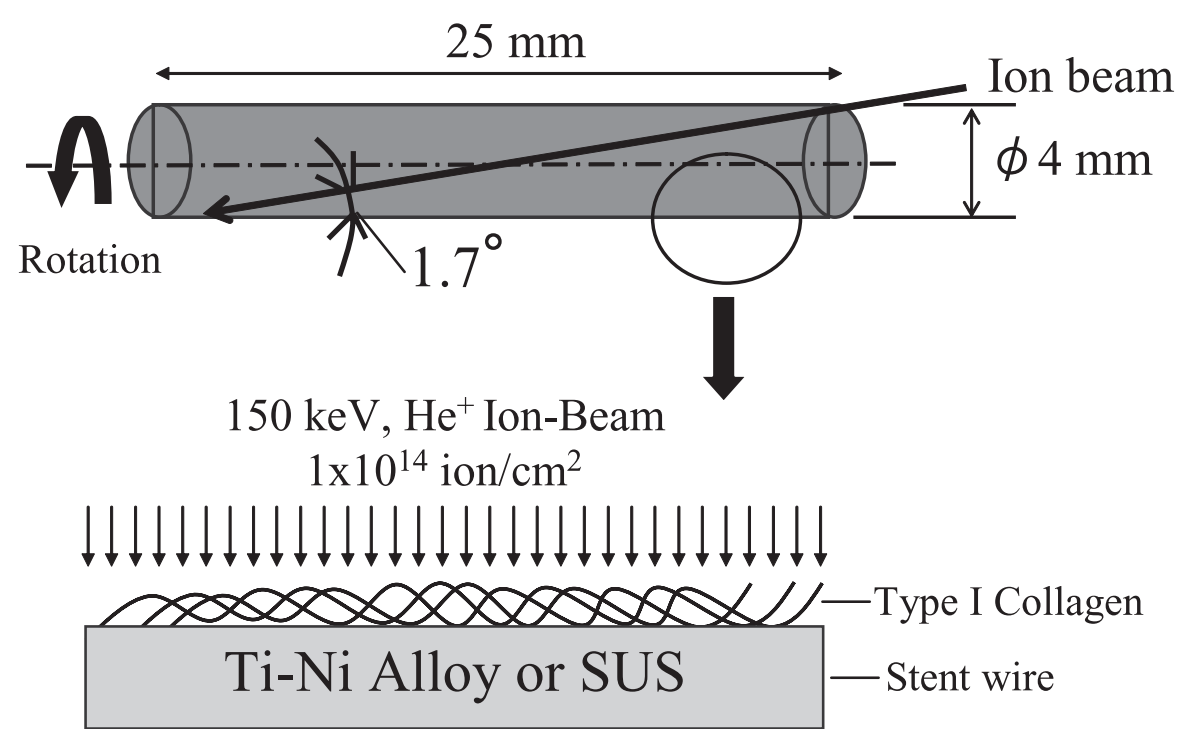

Fig. 2 A schematic diagram of ion-implanted collagen-coated small diameter stent. lon implantation was performed inner surface of the stent.

圧 $150 \mathrm{keV}$ で $1 \times 10^{14} \mathrm{ions} / \mathrm{cm}^{2}$ 傾斜回転照射法によりステ ント内面へのイオンビーム照射を行った。

\section{3. 急性動物実験}

ニチノール製ステント，コラーゲン複合化ニチノール製 ステントをビーグル犬の大腿動脈末梢に 2 時間留置し, 目 視および走査電子顕微鏡 $(\mathrm{SEM})$ によりステント表面への 血栓形成状態を観察した。抗凝固療法, 抗血小板療法は施 さなかった。

\section{4. 慢性動物実験}

ニチノール製ステント, ジョンソンエンドジョンソン社 BX ステントをディップコート法によりタイプI コラーゲ ンをコートした．乾燥後, $\mathrm{He}^{+}$イオンビーム照射を行っ た. ステントをビーグル犬の大腿動脈末梢に 2 力月留置し, 血管造影による慢性期の開存性評価求よび病理組織学的検 査を行った，留置時以外は抗凝固療法，抗血小板療法は施 さなかった。

\section{5. 薬物除放性ステントとの比較}

比較としてジョンソンエンドジョンソン製薬物徐放性入 テント (Cypher)を用いた。大腿動脈の両足に評価ステン 卜, 薬物徐放性ステントを 2 力月留置して, さらに抗血小 板療法 (チクロピジン $5 \mathrm{mg} / \mathrm{kg}$, アスピリン $81 \mathrm{mg}$ /錠)を 行った.

\section{結果と考察}

\section{1. 急性動物実験}

Fig. 3 にニチノールステントおよびコラーゲン複合化イ オンビーム照射ニチノールステントをビーグル犬大腿動脈 両足に 2 時間留置したのちのステントおよびステント表面 のSEM写真を示す。目視ではニチノールステントにはわ ずかな赤色血栓の形成がみられたが，コラーゲン複合化イ オンビーム照射ステントでは血栓形成はみられなかった。 SEMによる所見ではニチノールステント表面には血小板 の粘着とともにフィブリンネットワークの形成が観察され たのに対して，コラーゲン複合化イオンビーム照射ステン 卜は血小板粘着および血栓形成はみられず，良好な抗血栓 性を示した。

コラーゲンに $\mathrm{He}^{+}$イオンビームを加速エネルギー 150 $\mathrm{keV}$ で $1 \times 10^{14} \mathrm{ions} / \mathrm{cm}^{2}$ 照射した表面をステント表面に導 入し動物実験にて検証した結果，急性期でも良好な抗血栓 性を示した.

\section{2. 慢性動物実験}

Fig. 4 にコラーゲン複合化イオンビーム照射ニチノール ステントをビーグル犬大腿動脈に540日留置したのちのス テント表面㧍よび組織写真 (アザン染色)を示す．抗凝固療 法，抗血小板療法は一切行っていない，イオンビームを照 射したステントを留置した血管内面は，肉眼的に血栓の生 成はみられず，血管内皮細胞と考えられる白色の膜でステ ント材料が取り込まれていることが観察された。また組織 学検査では切片作成の際，ニチノール製ステントを引き抜 

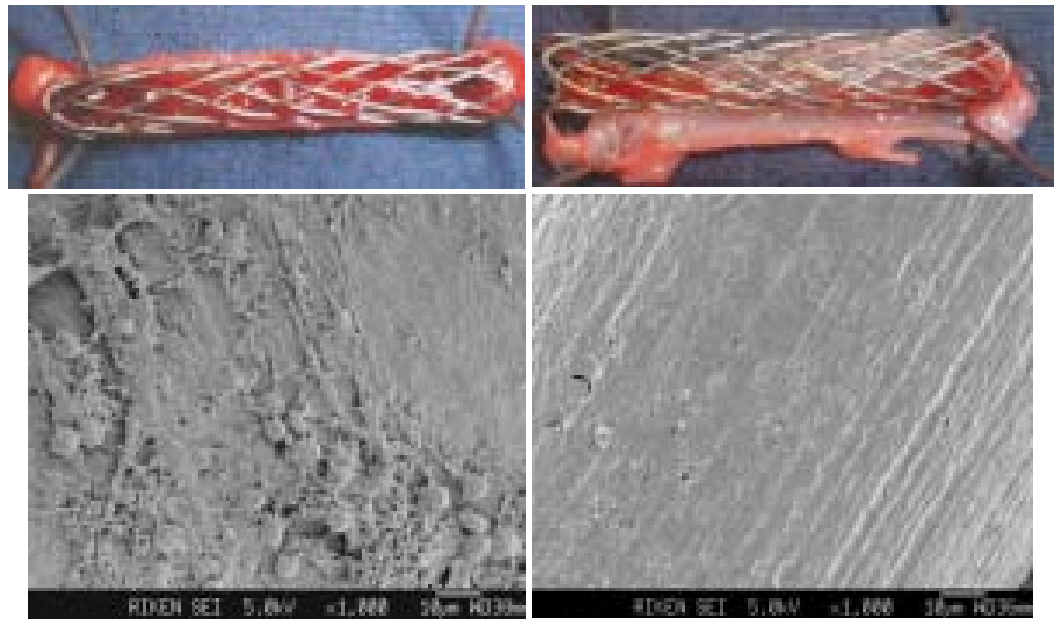

Fig. 3 Non-ion implanted Ti-Ni stent $(\mathrm{A})$ and $\mathrm{He}^{+}$ion implanted collagen-coated $\mathrm{Ti}$ Ni stent (B) with a fluence of $1 \times 10^{14}$ ions $/ \mathrm{cm}^{2}$ after 2 hours and scanning $A \mid B$ electron micrographs.
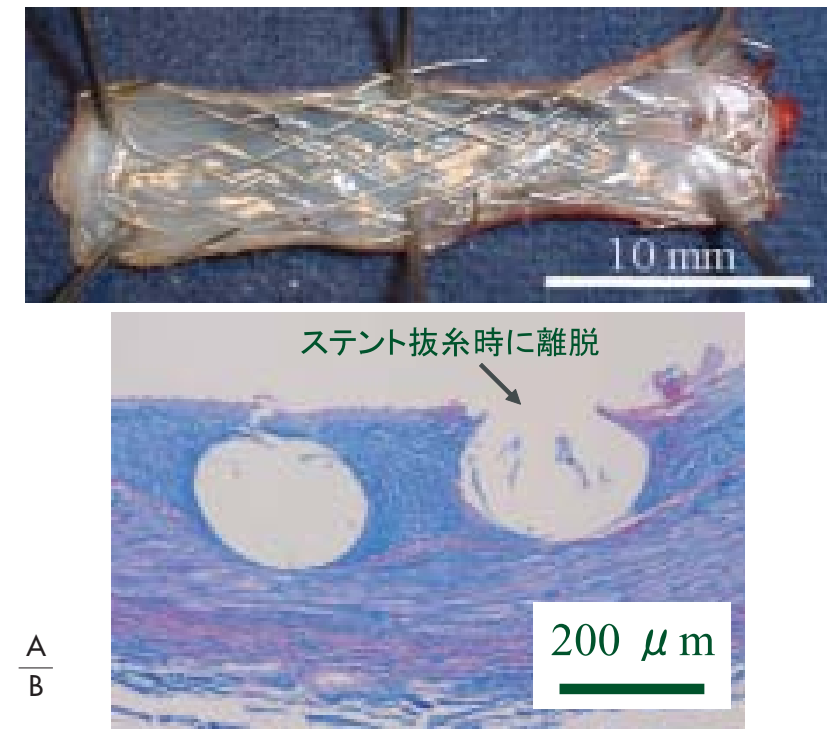

Fig. 4 Inner surface of $\mathrm{He}^{+}$ion implanted collagen-coated TiNi stent (A) after 540 days and histology (B).

いたのちに行ったため一部の血管内宮側のステント表面の 組織がその作業で脱落してしまったが，ステント部をまた がる内皮化が観察された。

Fig. 5 に留置 1 カ月以上のニチノールステントおよびコ ラーゲン複合化イオンビーム照射ステントの開存率を示 す．未処理のニチノールステントは 10 例中 1 例の開存の みであったが，コラーゲン複合化イオンビーム照射ステン 卜は 20 例中 16 例の開存性を得た。

Fig. 6 にコラーゲン複合化イオンビーム照射 BX ステン 卜 (拡張時 内径 $3.5 \mathrm{~mm}$, 長さ $15 \mathrm{~mm}$ ) をビーグル犬大腿動 脈に 2 力月留置したのちのステント表面およびSEM写真

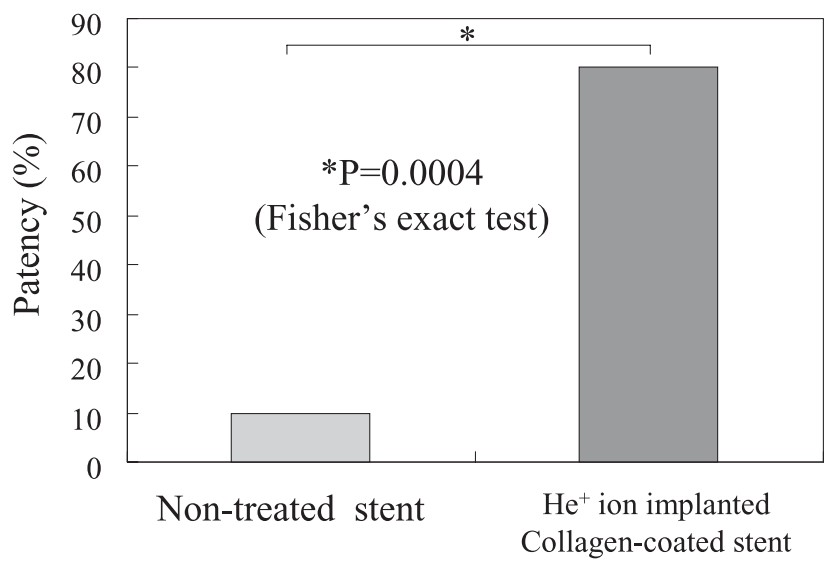

Fig. 5 Patency of non-treated Ti-Ni stent and $\mathrm{He}^{+}$ion implanted collagen-coated Ti-Ni stent over 30 days.

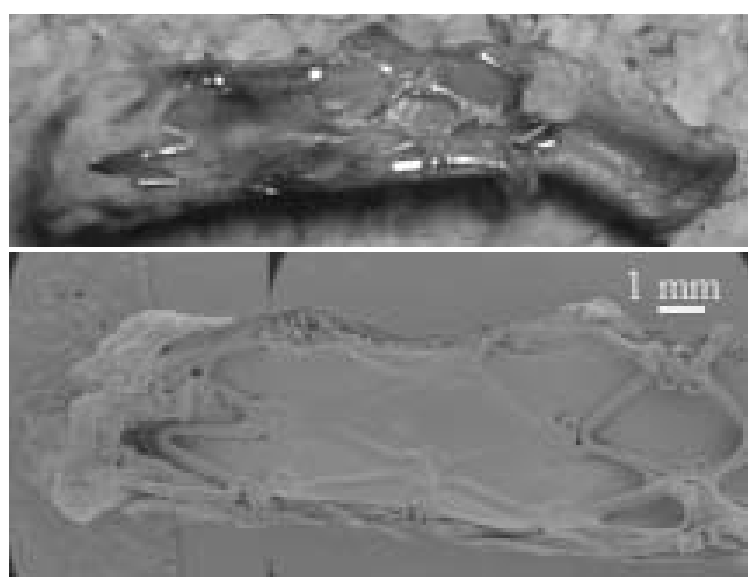

Fig. 6 Inner surface of $\mathrm{He}^{+}$ion implanted collagen-coated BX stent $(\mathrm{A})$ after 2 months without antiplatelet or anticoagulant and scanning electron micrograph (B). 

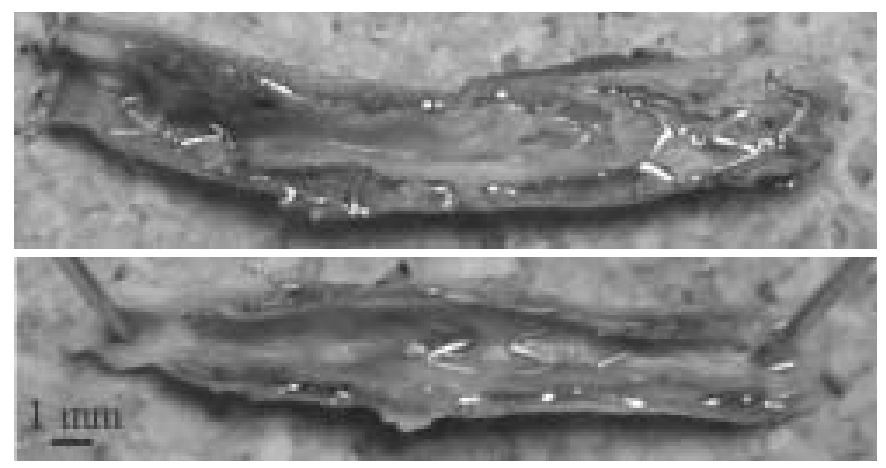

Fig. 7 Inner surface of Cypher stent (A) and $\mathrm{He}^{+}$ion implanted collagen-coated BX stent (B) after 2 months with antiplatelet.

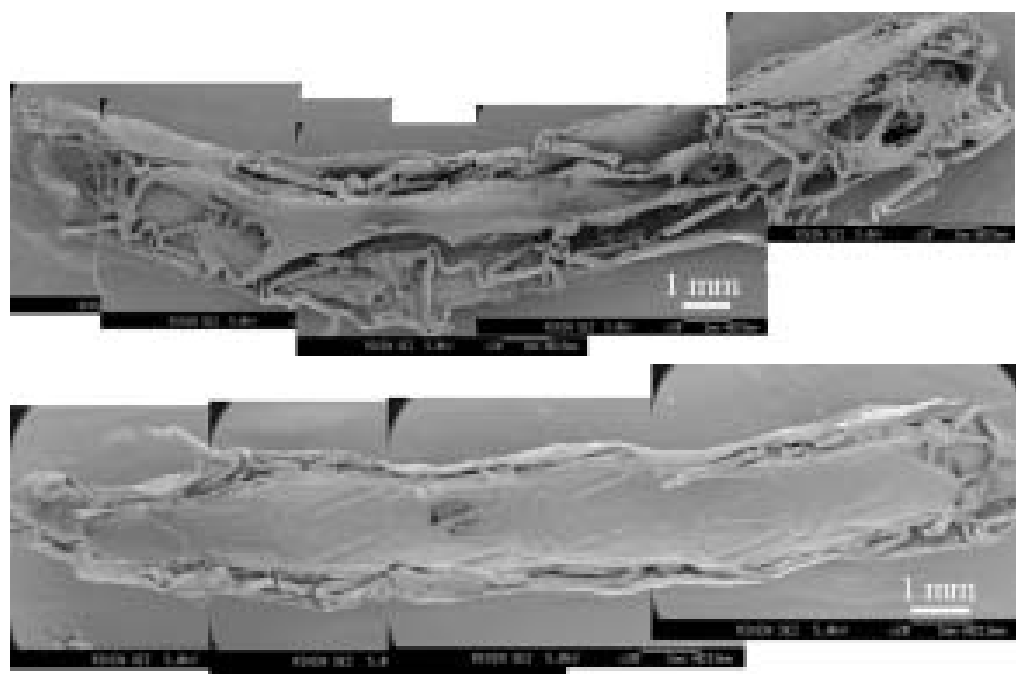

Fig. 8 Scanning electron micrographs of inner surface of Cypher stent $(A)$ and $\mathrm{He}^{+}$ion implanted collagen-coated BX stent (B) after 2 months with antiplatelet.

を示す．抗凝固療法，抗血小板療法は一切行っていない。 血栓形成はみられずまたステントをまたがる良好な内皮化 も観察された。

市販のステント表面にコラーゲンをコーティングし， $\mathrm{He}^{+}$イオンビーム照射することで良好な抗血栓性と自己 修復性を発揮することが判明した。

\section{3. 薬物除放性ステントとの比較}

現在最も使用されているステントはジョンソンエンドジ ヨンソン製薬物徐放性ステント (Cypher) である。このス テントとコラーゲン複合化イオンビーム照射ステントの生 体反応性を比較するため抗血小板療法を施した系でビーグ ル犬大腿動脈両足に留置した。未処理の $3.0 \mathrm{~mm}$, 長さ $18 \mathrm{~mm}$ の市販の薬物徐放性ステントとコラーゲンをコー ティングして $\mathrm{He}^{+}$イオンビーム照射した BX ステントを， 抗血小板療法(チクロピジン，アスピリン)を施した同一の
ビーグル犬の大腿動脈に 2 カ月留置した。評価は 2 匹のビ ーグル犬を用いて行った $(\mathrm{n}=2)$. Fig. 7 にステントの内面 写真，Fig. 8 にSEM写真を示す. 薬物徐放性ステントは 内面に非常に剝離しやすい厚い組織層がみられたが，コ ラーゲンコートイオンビーム照射ステントは薄く良好な安 定した内皮化を促進することがわかった。この現象は他の 1 匹の留置実験でも同様の実験結果が得られた。

\section{結 論}

タイプIコラーゲンをコーティングしてイオンビームを 照射し, 血小板粘着抑制, 細胞接着性を付与したニチノー ル製ステントおよび市販の冠動脈ステントをビーグル犬の 大腿動脈に抗凝固剂，抗血小板剂を施さない系で 2 力月留 置した結果，良好な抗血栓性と安定した内皮化が観察され た.

また抗血小板療法を施した系で市販の薬物徐放性ステン 
トとコラーゲン複合化イオンビーム照射ステントを比較し た結果，コラーゲン複合化イオンビーム照射ステント表面 はきわめて安定した内皮化が観察された。

以上の結果からコラーゲンに $\mathrm{He}^{+}$イオンビーム照射し た表面をステント表面に導入することによって, 抗凝固療 法, 抗血小板療法を軽減でき, かつ安定した内皮化層を形 成することによって再狭窄を防止できる可能性を示唆し た。

\section{文献}

1) Guglielmi G, Vinuela F, Dion J, et al: Electrothrombosis of saccular aneurysms via endovascular approach. Part 2: Preliminary clinical experience. J Neurosurg 75: 8-14, 1991

2) Guglielmi G, Vinuela F, Sepetka I, et al: Electrothrombosis of saccular aneurysms via endovascular approach. Part 1: Electrochemical basis, technique, and experimental results. J Neurosurg 75: 1-7, 1991

3) Ishihara K, Shibata N, Tanaka S, et al: Improved blood compatibility of segmented polyurethane by polymeric additives having phospholipid polar groups. $J$ Biomed Mater Res 32: 391-399, 1996

4) Kurotobi K, Suzuki Y, Kaibara M, et al: In vitro and in vivo study of ion-implanted collagen for the substrate of small diameter artificial grafts. Artif Organs 27: 582-586, 2003

5) Kurotobi K, Kaibara M, Suzuki Y, et al: Plasma protein adsorption onto cell attachment controlled ion implanted collagen. Nuclear Inst and Methods in Physics Research B: 175-177, 791-796, 2001

6) Kurotobi K, Kaibara M, Suzuki Y, et al: Ion implantation into collagen-coated surfaces for the development of small diameter artificial grafts. Colloids Surf B Biointerfaces 19: 227-235, 2000

7) Lanzino G, Kanaan Y, Perrini P, et al: Emerging concepts in the treatment of intracranial aneurysms: stents, coated coils, and liquid embolic agents. Neurosurgery 57: 449459, 2005

8) Nojiri C. Okano T, Jacobs HA, et al: Blood compatibility of PEO grafted polyurethane and HEMA/styrene block copolymer surfaces, J Biomed Mater Res 24: 1151-1171, 1990

9) Suzuki $\mathrm{Y}$, Iwaki M, Takahashi N, et al: In vitro and in vivo study of $\mathrm{He}^{+}$ion irradiated collagen for development of small diameter stent graft material. Nuclear Inst and Methods in Physics Research B 232: 353-357, 2005

10) Williams SK, Rose DG, Jarrell BE: Microvascular endothelial cell sodding of ePTFE vascular grafts. J Biomed Mater Res 28: 203-212, 1994 